\title{
HBV DNA Level Finding
}

National Cancer Institute

\section{Source}

National Cancer Institute. HBV DNA Level Finding. NCI Thesaurus. Code C157507.

The viral load of hepatitis b virus DNA units in a blood sample. 